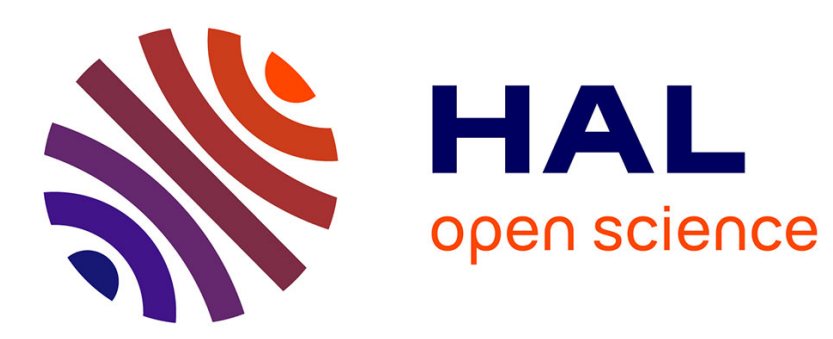

\title{
Pricing Innovation: State of the Art and Automotive Applications \\ Jean-Jacques Chanaron
}

\section{To cite this version:}

Jean-Jacques Chanaron. Pricing Innovation: State of the Art and Automotive Applications. International Journal of Vehicle Information and Communication Systems, 2008, 1 (n 3-4), pp. 268-287. halshs-00371047

\section{HAL Id: halshs-00371047 https://shs.hal.science/halshs-00371047}

Submitted on 21 Apr 2009

HAL is a multi-disciplinary open access archive for the deposit and dissemination of scientific research documents, whether they are published or not. The documents may come from teaching and research institutions in France or abroad, or from public or private research centers.
L'archive ouverte pluridisciplinaire HAL, est destinée au dépôt et à la diffusion de documents scientifiques de niveau recherche, publiés ou non, émanant des établissements d'enseignement et de recherche français ou étrangers, des laboratoires publics ou privés. 


\title{
Pricing Innovation: State of the Art and Automotive Applications Professor Jean-Jacques CHANARON* \\ CNRS \& GEM, France
}

\begin{abstract}
The paper aims at elaborating on pricing and business models for forthcoming innovative ITS devices, limiting its scope in particular to in-vehicle driving assistance systems and suggesting the various possible innovation and pricing strategies with theoretical discussions.

The methodology is based on a comprehensive literature review of the major contributions made by the fields of managerial economics and management sciences to the study of pricing strategies and practices and, in particular, the pricing of innovative goods or services, in order to identify the strengths and weaknesses of the various schools of thought. The paper also gathers and analyzes the available data on two innovative navigation and safety devices for cars, namely ABS (Anti-Lock Braking System) and navigation systems, in order to put forward an initial interpretation.
\end{abstract}

It concludes that there is no formula or even a vague method for determining "acceptable" price levels or "trigger points". There are two options, i.e. disruptive innovation which is by essence very risky and incremental innovation with each major model renewal.

\section{Key Words}

Innovation, pricing, automobile, intelligent transportation system

\section{Biographical notes}

Professor J.J. Chanaron is currently Research Director within the French National Centre for Scientific Research (CNRS) and Chief Scientific Advisor at the Grenoble Graduate School of Management.

Jean-Jacques has published extensively via books, articles in refereed journals and conference papers in Industrial Economics, Economics of Innovation and Technology Management since 1973 when he received his $\mathrm{PhD}$ at the University of Grenoble. He also holds a HDR in Economics since 1994. He is Associated Professor and Researcher with Henley Management College, Manchester University and Newcastle University in the UK as well as Tongji University in Shanghai, China. He is a well-recognized expert in the automotive industry. He is consultant to International Organizations (EU, OECD, ILO, UNIDO), professional organizations (CCFA, FIEV, JAMA, CLEPA), OEMs (PSA, Renault, Toyota, Nissan, DaimlerChrysler, VW) and numerous component manufacturers. He is a member of the French Society of Automotive Engineers (SIA) and the GERPISA International Network of Researchers on the Auto Industry.

In April 2004, he has been granted the IAMOT award for research excellence in Technology and Innovation Management.

\footnotetext{
${ }^{*}$ CNRS/GATE - Grenoble School of Management - 324 Chemin des Chartreux - 38430 MOIRANS FRANCE

Tel: +33622962001 - E-mail : jean-jacques.chanaron $@$ wanadoo.fr.
} 


\section{INTRODUCTION}

The pricing of common goods and services is one of the key factors governing microeconomic models of competition, monopoly and oligopoly. As a result, there is a vast amount of theoretical literature on the topic. The same cannot be said for the pricing of innovative goods and services. In all likelihood, this is because the necessary conditions do not yet exist: this refers in particular to the existence of the market itself-in other words, the conjunction of supply and demand. In addition, the dominant economic theory considers innovation a source of cost savings, rather than the creator of brand new markets. The most recent research by transport economists relates to the price adjustment policies that are applied to transport in an attempt to better take into account its "real" costs, that is to say, the social costs of the different forms of transport (European Commission, 2001). However, the existing literature does not even broach the subject of pricing for innovative goods.

The aim of this article is threefold:

- Firstly, to review the existing economic and management sciences literature on the topic of price determination and, in particular, the pricing of new goods and services. The objective here will be to identify the strengths, weaknesses, contributions and failings of the different fields and the main schools of thought;

- Secondly, to gather and analyze the available pricing and sales information concerning two innovative navigational and safety aids for cars-ABS (Anti-Lock Braking System) and navigation systems - and to build up an initial interpretation of this data.

- Thirdly, to elaborate hypotheses and scenarios on pricing and business models for the forthcoming ITS (Intelligent Transportation Systems) devices, focusing in particular on invehicle driving assistance systems.

\section{MICROECONOMIC PRICE THEORY}

\subsection{Market prices}

In the market, whatever its form, price is one of the arithmetic variables of unit profit ${ }^{1}$, together with average cost. While average cost is a techno-economic variable that is managed by each company internally in order to determine the minimum price below which the firm will decline to offer its product, price also depends on the acceptance level of buyers, which governs the maximum price beyond which the consumer will refuse to purchase the good.

The two extremes of market economics - pure perfect competition and monopoly - are very different from a price determination point of view. In a competitive situation, the market does indeed determine the price: the company is the "price taker" at a point of equilibrium between the price consumers are prepared to pay and the marginal cost above the minimum average price.

\footnotetext{
${ }^{1} \pi=\mathrm{p}-\mathrm{AC}$
} 
In a monopoly situation, the supplier sets the price. The company is the "price maker" of a quantity that enables marginal revenue and marginal cost (above the average price) to be balanced, a quantity that, in turn, determines the price that consumers are then prepared to pay. However, the company remains dependent on the state of demand and, in particular, the price elasticity of demand.

In other situations of imperfect competition-oligopoly, dominant firm-there is no simple model for price determination. This is a gray area of strategic games and decisions.

Situations of imperfect competition that are not strictly monopolistic are in a clear majority. Price determination is therefore a highly strategic issue that is dependent on anticipation and on certain choices that follow no stable economic model.

In practice, when the company is in a position to set its price, the most commonly employed method is that which involves adding together cost and expected profit ${ }^{2}$. When the market is competitive, the price is determined by the market. The company therefore has a target price, based on which it sets an ad hoc cost estimate for an expected average profit. It then designs the product or service according to this "imposed" cost.

\subsection{The price of innovation}

The economic theory of innovation, first proposed by Schumpeter (1912), allows the innovating company to enjoy a temporary monopoly situation, because, by definition, it is alone in the newly-created market. Therefore, in this case the company is the "price maker" until the moment imitators enter the market, attracted by the profits achieved by the innovator (Chanaron, 1990).

There are three alternative ways of setting the price of an innovation:

1. The monopolist innovator's price or "premium pricing", which is based on high costs and the acceptability of a cost premium on the new good. This is common practice in the car industry, where innovations are introduced at the top of the line. This is also the dominant practice in pharmaceuticals and in the electronic component (Intel Pentium) and software industries. This pricing strategy is sometimes termed "cream skimming pricing" insofar as in certain high-technology markets, there are always consumers who are prepared to pay a premium for novelty- the "early adopters"3;

In the case of export markets, different prices can be set, most notably as a function of exchange rate differences (Khalaf, Kichian, 2000), or varying price or income elasticities.

Glaxo's launch of the anti-ulcer drug Zantac, in 1983, is one of the best-known examples of successful "premium pricing". For patients, the greater perceived value of Zantac compared with Tagamet by SmithKline Beecham, the world leader in the segment at the time, meant a more convenient dosing schedule, fewer side effects and no drug contraindications. Glaxo decided to charge a $50 \%$ premium instead of pricing at parity or below ("follower pricing"). In four years, Zantac became the world market leader.

\footnotetext{
${ }^{2}$ Cost-plus pricing.

${ }^{3}$ This strategy can also be justified by the need to recoup R\&D costs from initial sales.
} 
2. Market pricing or competitive pricing, which takes into account the option to choose alternatives to the innovative product or service - as well as balancing supply and demandwhile allowing for manufacturers' cost constraints and the economic satisfaction (well-being) of consumers;

One of the possible variants of market pricing is the strategy known as "value pricing". This involves banishing any form of price promotion (e.g. discounts, coupons), while increasing advertising costs and passing them on to the consumer "normally". According to Ailawadi, Lehmann and Neslin (2001), this strategy was successfully applied by Procter \& Gamble as of $1991^{4}$.

3. The loss-leader price, which in its extreme form, can mean that the product is free or practically free. This takes into account the need to create demand for a new consumer product from scratch or the fact that the product has to compete against a dominant alternative standard or technology and/or that its use can generate other sources of revenue: Minitel, mobile telephony, the Linux operating system ${ }^{5}$, Netscape source code, Encyclopedia Britannica $^{6}$, Internet browsing.

Klemperer (1995) introduced an alternative to the "premium pricing" strategy that takes into account the notion of diffusion over time. This is the limit price strategy that allows an innovative company that is still alone in its market and has the potential to generate "switching costs" to "capture" the largest possible market share in order to minimize the size of the remaining market, i.e. consumers who are not loyal to the brand, when new companies enter the market.

Holden and Nagle (1998) put forward the notion of "kamikaze pricing" to describe the penetration strategies that employ loss-leader prices for such long periods of time that they result in situations in which none of the competitors succeed in obtaining acceptable returns on investments. Penetration pricing strategies are viable if the product or service is sold at its true value $^{8}$.

The body of management science literature on the subject of price setting has been extended considerably with the emergence of online business ${ }^{9}$. Indeed, the pricing of online services is a major strategic issue for banks, insurance companies, auctioneers. In addition, as Pourquery (2001) points out, the overriding attitude of consumers to pricing has been profoundly altered by the Internet, which has enriched the culture of consumers with the concept of auctions and the idea that prices can change very quickly. The Internet also offers users the option of

\footnotetext{
${ }^{4}$ Between 1990 and 1996, purchasing frequency dropped by $15.7 \%$ and discount coupon usage fell by $54.3 \%$. As a result, the average price paid by consumers increased by around $20 \%$.

${ }^{5}$ On August 25, 1991, Linus Torvalds posted a message on comp.os.minix stating that the source code of his minix system would be free: "Hello everybody out there using minix. I'm doing a (free) operating system (just a hobby, won't be big and professional ... for 386(486) AT clones. This has been brewing since April, and is starting to get ready".

${ }^{6}$ Previously sold for $\$ 1,500$, now partially available online free of charge.

${ }^{7}$ The cost incurred by consumers when changing suppliers.

${ }^{8}$ The authors (of the Strategic Pricing Group) cite Lexus (Toyota), which was launched in the United States at a higher price than standard vehicles but still undercut Mercedes Benz and BMW prices.

${ }^{9}$ The special report that appeared in the Expansion Management Review in December 2001, for example.
} 
instantaneously comparing the prices of different suppliers (PriceSearch.com) and of modifying any online price list (Schindehutte and Morris, 2001).

In practice, according to Smith and Nagle (1994), the price set for a new product or service is often the result of a "political" decision which emanates from the confrontation between strict accounting requirements - the price needs to be high enough to cover development and production costs - and a vision based more on marketing - the price must be low enough for the commodity to sell.

According to management sciences, price is one of a number of strategic variables. It is also an extraordinarily complex issue (Cressmann, 2001) that must take into account consumer expectations (marketing) and the company's development strategy. Price is a signal sent by a company to its customers that reflects its analysis of the perceived value of a product.

\section{PRICE AND DEMAND}

Economic theories on demand are not as well-developed as those on the subject of supply. This is probably because it is extremely difficult to apprehend the immense variety of consumer behaviors, attitudes, motivations, choice criteria. In terms of managerial approaches, marketing is obviously the field that is supposed to allow these types of questions to be analyzed. But there is still a fair way to go before a field that works more like a cookbook than anything else becomes a bona fide scientific discipline.

Managerial approaches emphasize the strategic side of price: price represents the value the consumer expects to obtain from the product or service they have acquired; it varies over time and space; it can be diversified through different models and versions ${ }^{10}$; it is visible and indicative of value, image, quality; it is virtual because it is subject to modification (Schindehutte and Morris, 2001). On the automotive market, as confirmed by a survey carried out early 2005 by ACNielsen with 14,000 consumers on Internet ${ }^{11}$, globally, the price is unanimously the most important factor in choice of car. Surprisingly, the engine size and the environmentally friendly achievements are regarded the least important features when it comes to buying a car.

\subsection{Direct demand and derived demand}

In the automotive world, the demand for active and passive safety systems and driver aids is derived from the demand for new vehicles with so-called "factory-fitted" equipment (as standard or as an optional extra) or from the demand for accessories for so-called "aftermarket" equipment.

There are therefore two price determination methods:

- The double "loop", which combines the price charged by the equipment manufacturer to the car manufacturer with the price charged by the car manufacturer to the consumer, to which distribution costs and margins have been added;

\footnotetext{
10 "Versioning".

${ }^{11}$ See http://www2.acnielsen.com/news/20050404_eu.shtm1.
} 
- The single "loop", which is comprised of the price charged by the equipment manufacturer to the consumer, to which distribution costs and margins have been added.

\subsection{Price of the product and price of complementary goods}

In the automotive sector, there are obvious cross-elasticities with complementary goods. In the area of driving aids, the following immediately spring to mind: Firstly, the cost of updating software and boards; and secondly, connections to real-time information-update networks.

Chanaron (2001) notes that one of the problems faced by Toyota in marketing its Monet navigation systems, which are connected to the Internet, remains the pricing of the subscription to the network, as well as the consumer perception of adding another connection to the list of those already installed (e.g. fixed telephone, cell phone, television).

Indeed, in early 2002, the France CD-ROM for the Clarion Dayton navigation system was being sold for $€ 181$, for use with aftermarket systems that were available for between $€ 1,310$ and $€ 2,440$. The France Atlas CD-ROM (for the Clarion NVS613 system, which was sold at a recommended retail price of $€ 1,980$ ) was available for $€ 152$. This additional cost of almost $10 \%$ of the original purchase price is incurred by the user at least once a year.

\subsection{Purchase price and cost of usage}

One of the peculiarities of the car industry is that different levels of cost are incurred by the user/consumer. Indeed, because they are durable goods, cars inevitably lead to the consumption of many other goods and services that are inherent to their ownership and use.

Table 1. The cost of motoring

\begin{tabular}{|l|l|l|}
\hline Acquisition & Possession & Use \\
\hline$\bullet \begin{array}{l}\text { Price of the vehicle and } \\
\text { options }\end{array}$ & $\begin{array}{l}\bullet \text { Fuel } \\
\bullet \quad \text { Tnsurance } \\
\text { Vehicle registration }\end{array}$ & $\begin{array}{l}\text { Fuel tax } \\
\text { Tolls and fees (highways } \\
\text { and parking) } \\
\text { Maintenance and repair } \\
\text { costs }\end{array}$ \\
\hline
\end{tabular}

These different cost items are obviously interrelated. Their sensitivity to price and tax variations has been highlighted on numerous occasions (in particular, those relating to taxation, Chanaron, Kostopoulou, 1995a, 1995b). Negative cross-price elasticities are especially high for motor vehicles, which have an extendible physical lifecycle and a replacement date that is easy to alter, notably by switching from a new to a used vehicle and vice versa.

When an apparently significant innovation emerges in the fields of vehicle safety equipment or energy consumption and the product is expected to lead to the implementation of incentives or regulations, specialists are quick to suggest "compensating" for any resulting surcharges by introducing tax breaks or rebates. Similarly, the additional cost of safety equipment could be counterbalanced by a drop in insurance premiums or certain taxes. 


\subsection{Threshold effects}

The field of managerial economics, in its analysis of price determination, has identified certain threshold effects; in other words, price levels that trigger the emergence of a market or a significant change in the volume of demand. Marketing often attempts to pinpoint such thresholds through surveys of representative samples, which allow an acceptance threshold to be assessed.

According to the empirical studies conducted by Sahay (2000), in industrialized nations, a new product stands a greater chance of taking off if its price remains below the $€ 230$ threshold. In the opinion of Chanaron (2001), Toyota has estimated the psychological threshold for the price of first-generation navigation systems at around $€ 350-400$. For second-generation systems, with real-time updates, a subscription fee is added to the basic price of the equipment.

\subsection{Behavior}

Economists have always struggled to fully comprehend behavior, in particular because of its extreme diversity and tendency to vary over time and space, but also as a result of measurement difficulties, even when making approximations. The debate on the concept of value rages on!

Management sciences, on the other hand, have made significant progress, most notably by defining several main categories of consumers according to the speed with which they adopt technological innovations and, therefore, the price level they are likely to accept.

The sensitivity to market price grows over time, with innovators obviously being prepared to accept high launch prices. 


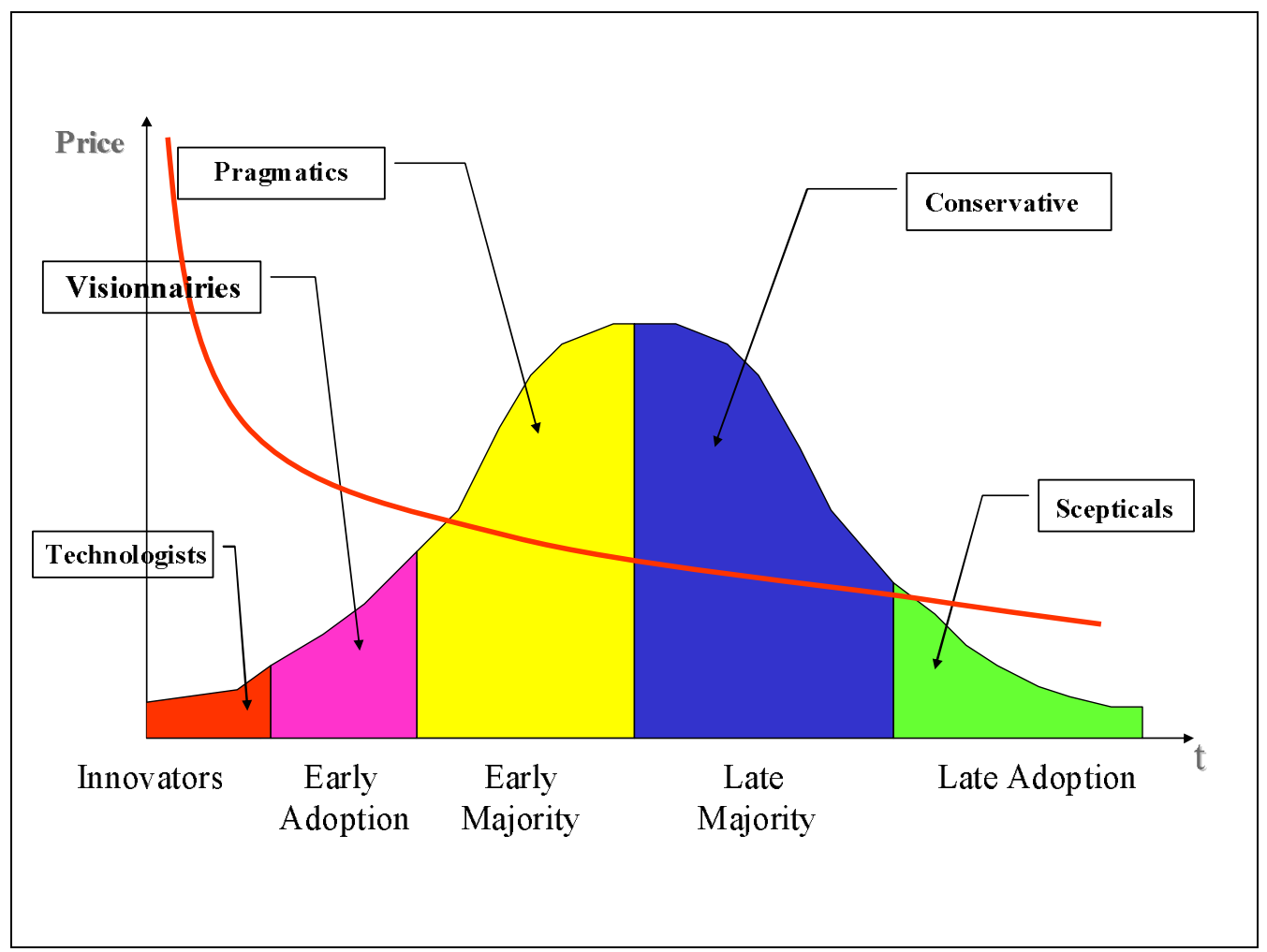

Figure 1. Price and Timing of Adoption

\section{6. "Lock-in" costs}

In many new information and communication technology applications, user/consumers can often find themselves in a "lock-in" situation; in other words, trapped as a result of their initial decision and forced to continue buying from the original equipment or software manufacturer, unless they are prepared to make a substantial investment in order to change suppliers ("switching cost").

From a product offering point of view, the aim is to encourage consumer loyalty and even to keep customers against their will or their best interests ${ }^{12}$. According to Klemperer $(1987 ; 1995)$, consumers or users can be trapped in a number of ways: by the transaction costs that are inherent to the renegotiation or termination of a supply contract; by the training cost involved in switching from a familiar product or service to a new product or service; by artificial transfer costs: loyalty agreements (online updates), discounts, bonuses, contracts; by the need for the old and new product or service to be technologically compatible; by uncertainties over the quality and performance of the new product; by the psychological cost of switching to a new and unfamiliar product or service.

Incidentally, many suppliers of software, updates, and performance or functional upgrades play on these transfer costs by charging high prices, backed up by the possibly justifiable claim that they need to recoup their initial investment, including R\&D costs (Pei-Yu, Hitt, 2001). According to Pei-Yu and Hitt (2001), these companies can then either reduce competition through pricing, or create a monopoly situation ${ }^{13}$ and thus enjoy substantial economic rent.

\footnotetext{
${ }^{12}$ Customer retention.

${ }^{13}$ By assuming a "first mover" position.
} 


\section{MARKET STRUCTURE AND PRICE}

Economic theory has developed reference models for markets with a competitive and monopolistic structure. However, it is far less well-equipped to deal with other situations of imperfect competition, in particular oligopolistic markets, which are, in fact, in a majority. Optimization subject to constraints does not cater for such situations, which over the years have become a subject of predilection for game theory and experimental economics.

In the automotive sector (de Banville, Chanaron, 1991), the oligopolistic structure of both vehicle production (Original Equipment Manufacturers or OEMs) and equipment manufacturing precludes strictly monopolistic practices, especially since national markets were opened to competition. It can even be said to constitute a considerable barrier to disruptive innovation (Chanaron, 1998).

However, when one of the market players finds itself, at least temporarily, in a unique position as a result of an innovation, as Bosch did with ABS at the end of the seventies and again with the common-rail direct injection diesel engine in the late nineties, the prices charged allow it to enjoy monopolistic rents.

Subsequently, Schumpeter's model for the diffusion of innovation through imitation takes root very quickly, with the potential for high profits attracting new entrants and the potential for lower prices prompting car manufacturers, in their role as customers, to call for further competitors to enter the market. It is thanks to this phenomenon that Siemens, Denso, TRW, Delphi and Visteon now manufacture common-rail direct injection diesel systems, with Peugeot agreeing to share its knowledge base with Siemens, in order to counter the market power wielded by Bosch.

\section{THE MANAGERIAL APPROACH TO PRICING POLICY}

The about-turn made by Microsoft barely a month after it launched the Xbox games console, which saw its price drop by $37.5 \%$ at the end of April 2002, illustrates the difficulties faced by companies. In his analysis of pricing policy, Briard (2002) describes its status as marketing's poor relation.

Price is the result of a consensus between functional approaches and interests that are often contradictory:

The Microsoft case clearly shows that because of the near-monopolistic pricing model Microsoft enjoys with its software, the firm's strategists may have been blinded by their success and caught out by the competitive structure of the console market. The case also pinpoints that untimely price changes can challenge the loyalty of early buyers, whose purchase will have been suddenly devalued and that analysts must fine-tune their optimal price determination model and must do so long before the new product is launched. Finally, the case shows that the different mindsets governing the various corporate divisions must be coordinated and probably require the appointment of a chief economist to reconcile the information available with the company's targets. 


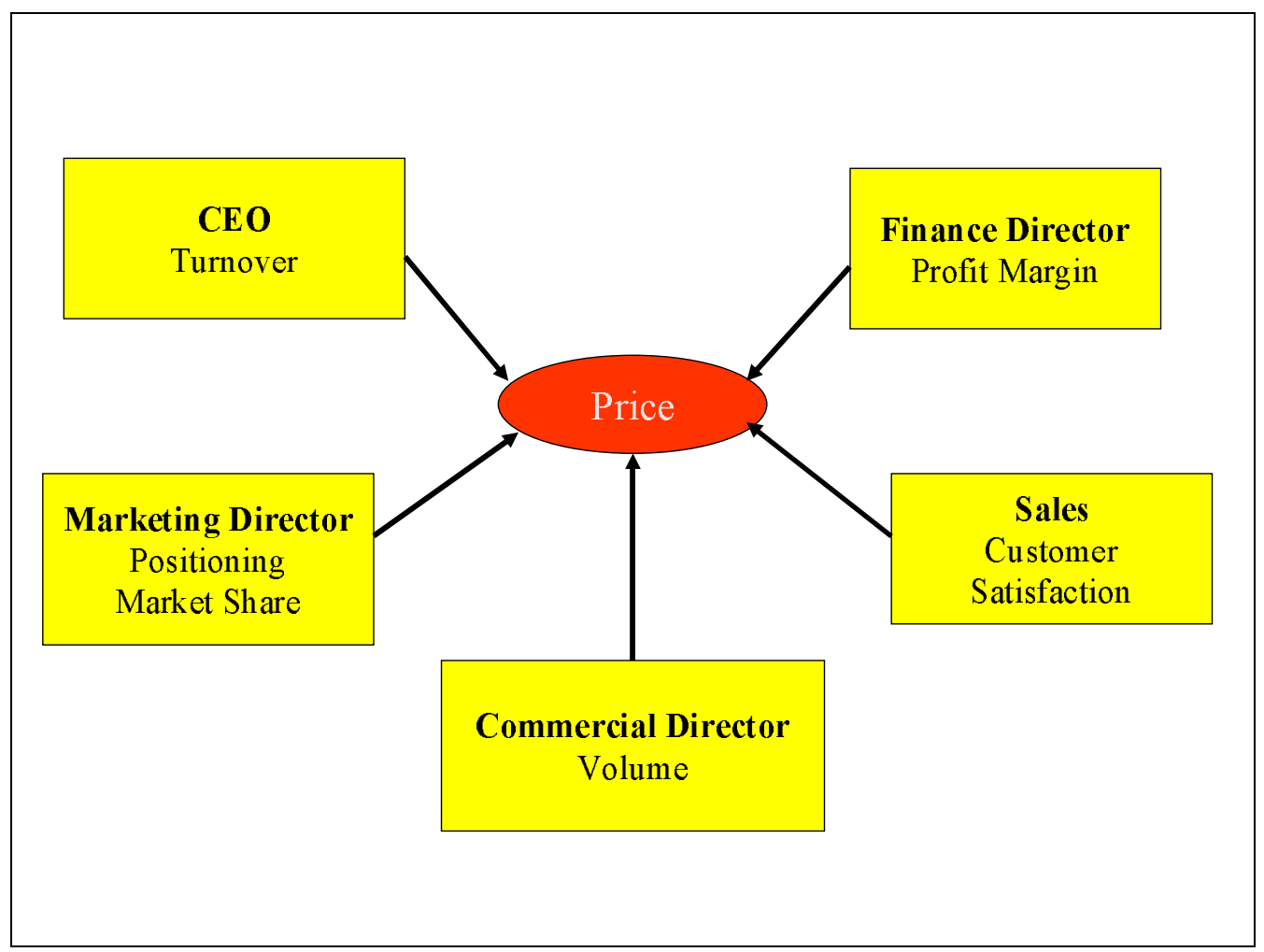

Figure 2. A Multi-rationale Managerial Decision Making Process

\section{PRACTICAL EXPERIENCES IN THE AUTOMOTIVE SECTOR}

Beyond their historical and educational value, case studies allow important lessons to be learned that can be applied to future innovations. Indeed, ABS (Anti-Lock Braking System) and navigation systems are two significant examples of components that enhance the safety and use of vehicles and which have followed exemplary innovation and diffusion processes.

\subsection{ABS systems}

ABS is a relatively recent example of an innovative, electronics-based active safety feature that has been on the market long enough for us to be able to identify and analyze the general trends that affect it.

Developed in the seventies and sold as an optional extra and later as standard equipment at the beginning of the eighties, essentially by German manufacturers of luxury automobiles, ABS can now be considered widespread, despite not yet being available on certain bottom-of-the-line models (or makes) and despite continued debate in the United States over its true value in terms of performance. 


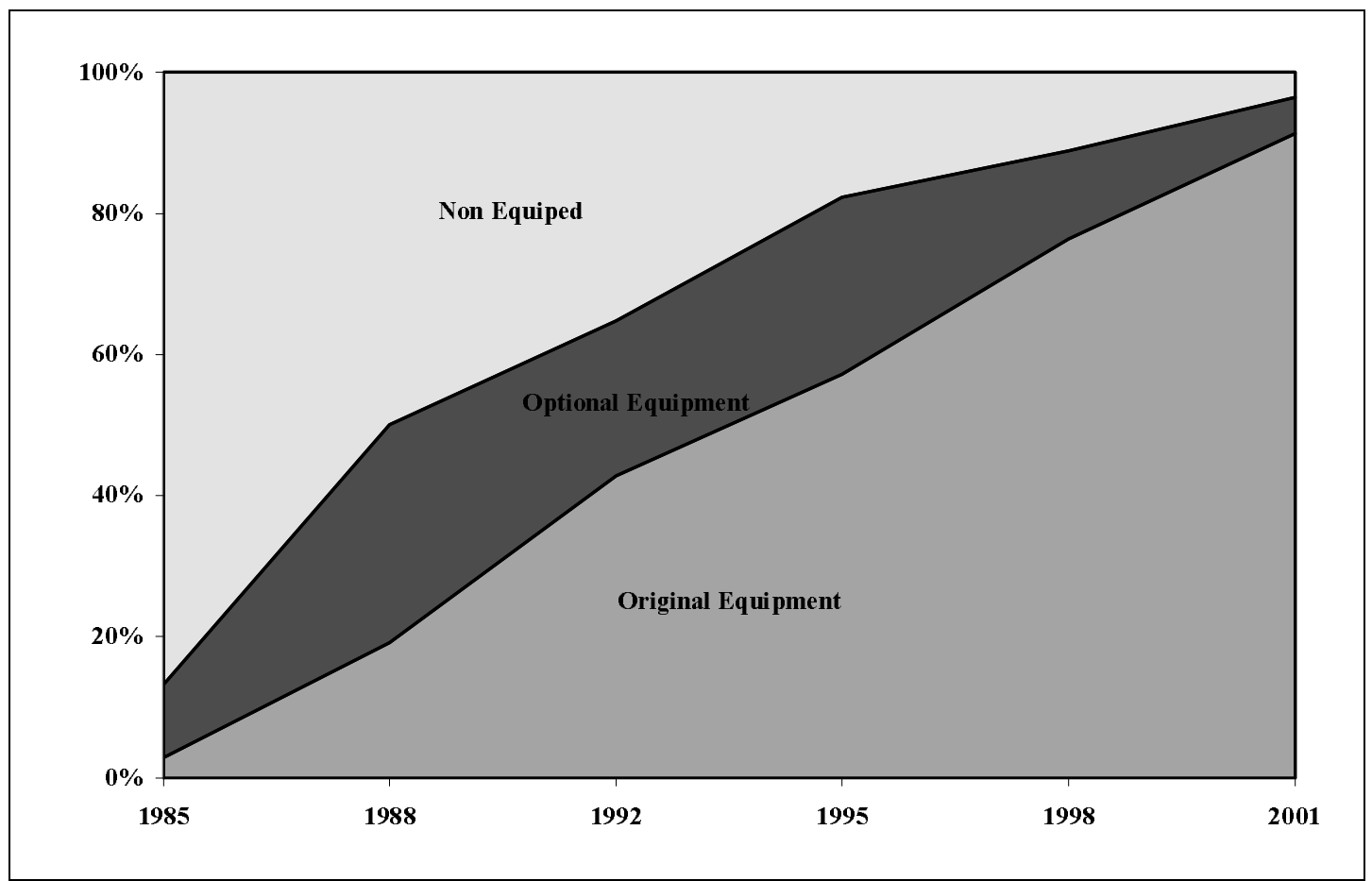

Figure 3. ABS Equipment Rate (in \% of models available on the Swiss market

It has therefore taken over twenty years for the widespread inclusion of ABS as standard to become a reality in Europe. In 2001, less than 4\% of models did not offer ABS as standard or as an option.

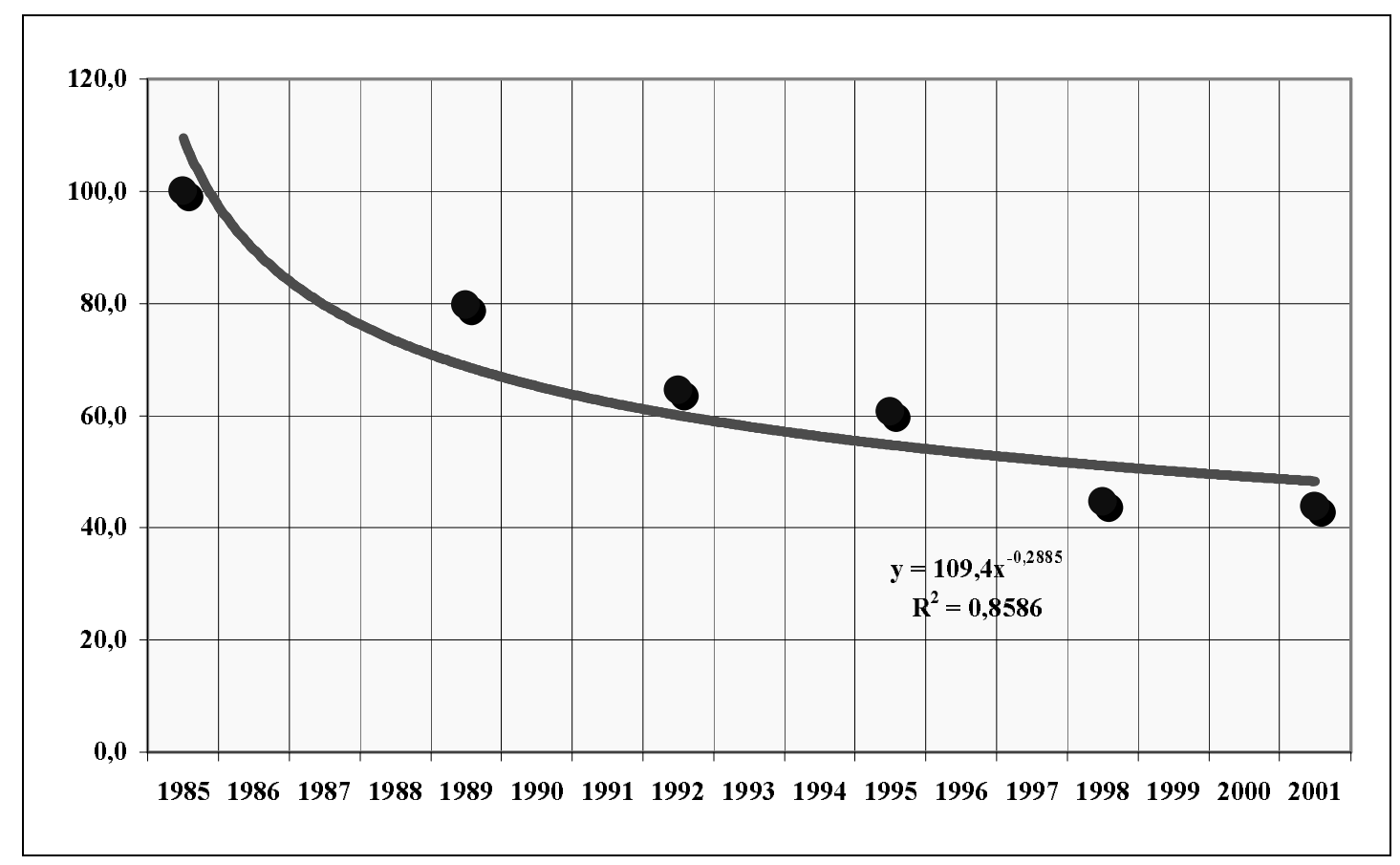

Figure 4. Optional Price of ABS System on the Swiss Market

How prices have progressed over time is obviously difficult to evaluate. In the absence of data from ABS system manufacturers, and because ABS is included in the list price of new vehicles, it is only possible to consider the price of optional ABS. The general trend observed fits exactly into the standard diffusion model. In fifteen years, prices halved, and have now stabilized. In 
2001, optional ABS represented around 5 to $6 \%$ of the vehicle's sale price. In 1985 , the figure was around 9 to $10 \%$.

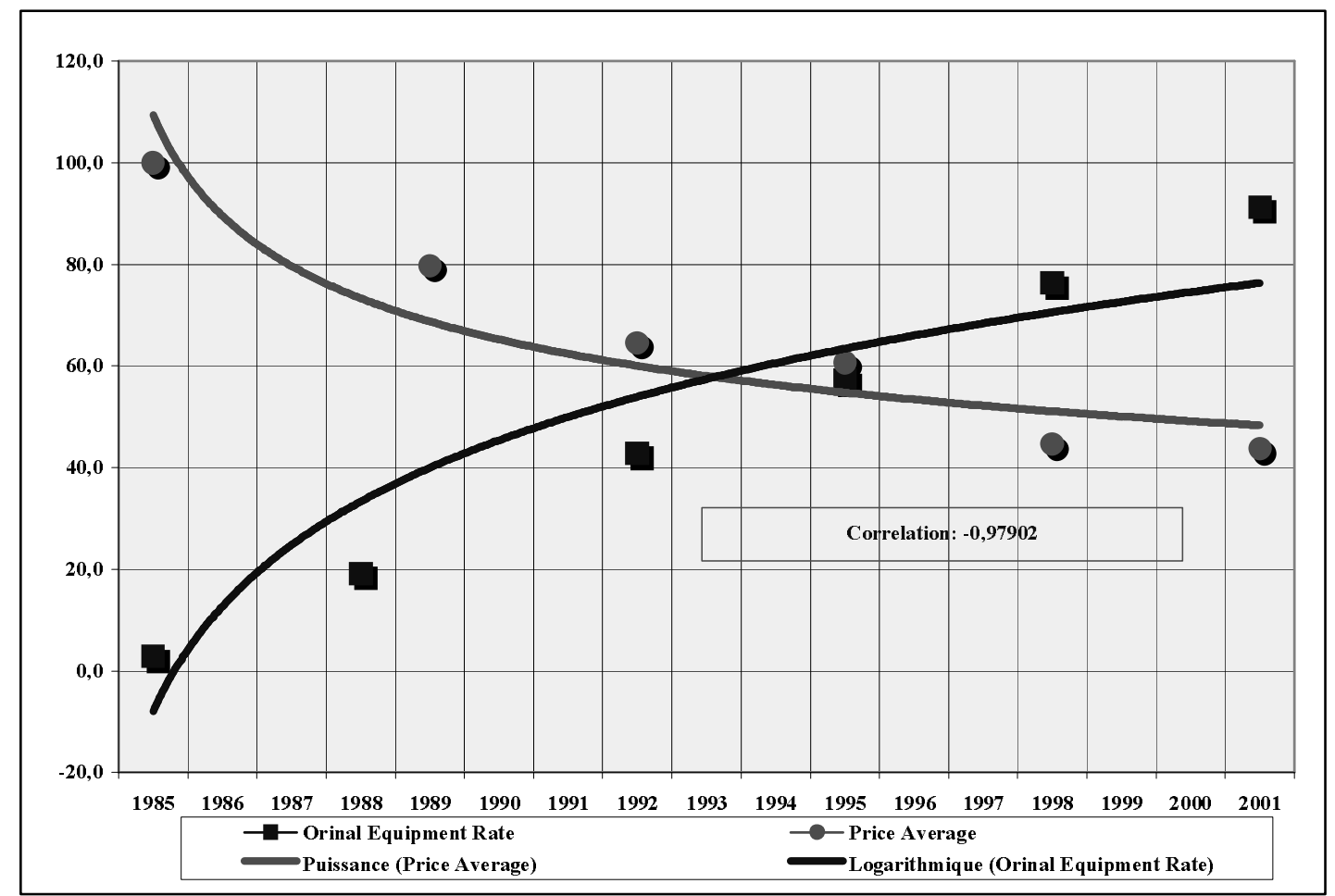

Figure 5. Synchronized Phenomena

\subsection{Navigation systems}

Satellite navigation systems were launched much more recently-in the mid-nineties-but we already have considerable information on their production, sales and prices in Japan, where their commercial success is unquestionable.

Prices for navigational aids vary greatly. At the end of 2001 , these ranged from $¥ 300,000$ $(€ 2,500)$ for a Pioneer system with a color monitor and DVD, for top of the line vehicles, to a loss-leader price of $¥ 58,000$ ( $€ 500$ ) for a Toyota system for compact vehicles. At the price charged for the Toyota system, the widespread fitting of such systems as standard equipment on all cars and light utility vehicles is foreseeable in the near future. The cost of updating the databases (CD-ROM or DVD) is considered to be marginal.

VICS (Vehicle Information and Communication System), which are connected to the Internet and provide real-time updates of traffic data, as well as more general information, are currently sold at around $€ 500-600$, with an additional subscription fee. According to Chanaron and Orselli (2001), when Toyota launched its Monet system, it had no choice but to set a reduced price that fell below the breakeven point.

In mid-February 2002, Nissan announced a March launch date for an integrated navigation system equipped with both an Internet connection and embedded mobile telephony. This would be fitted as standard to a new "compact" model for $¥ 50,000$, or $€ 430$, compared with $¥ 100,000$ for a traditional navigation system. The annual subscription fee was set at $¥ 4,000$, or $€ 35$, with Nissan planning to sell 50,000 of these vehicles in the first year. The price drop was staggering. 
This initiative prompted Toyota to launch its G-book in the second half of 2002 and led Honda to bring out a similar system at the end of 2002 in collaboration with NTT (Nippon Telegram and Telephone) $)^{14}$.

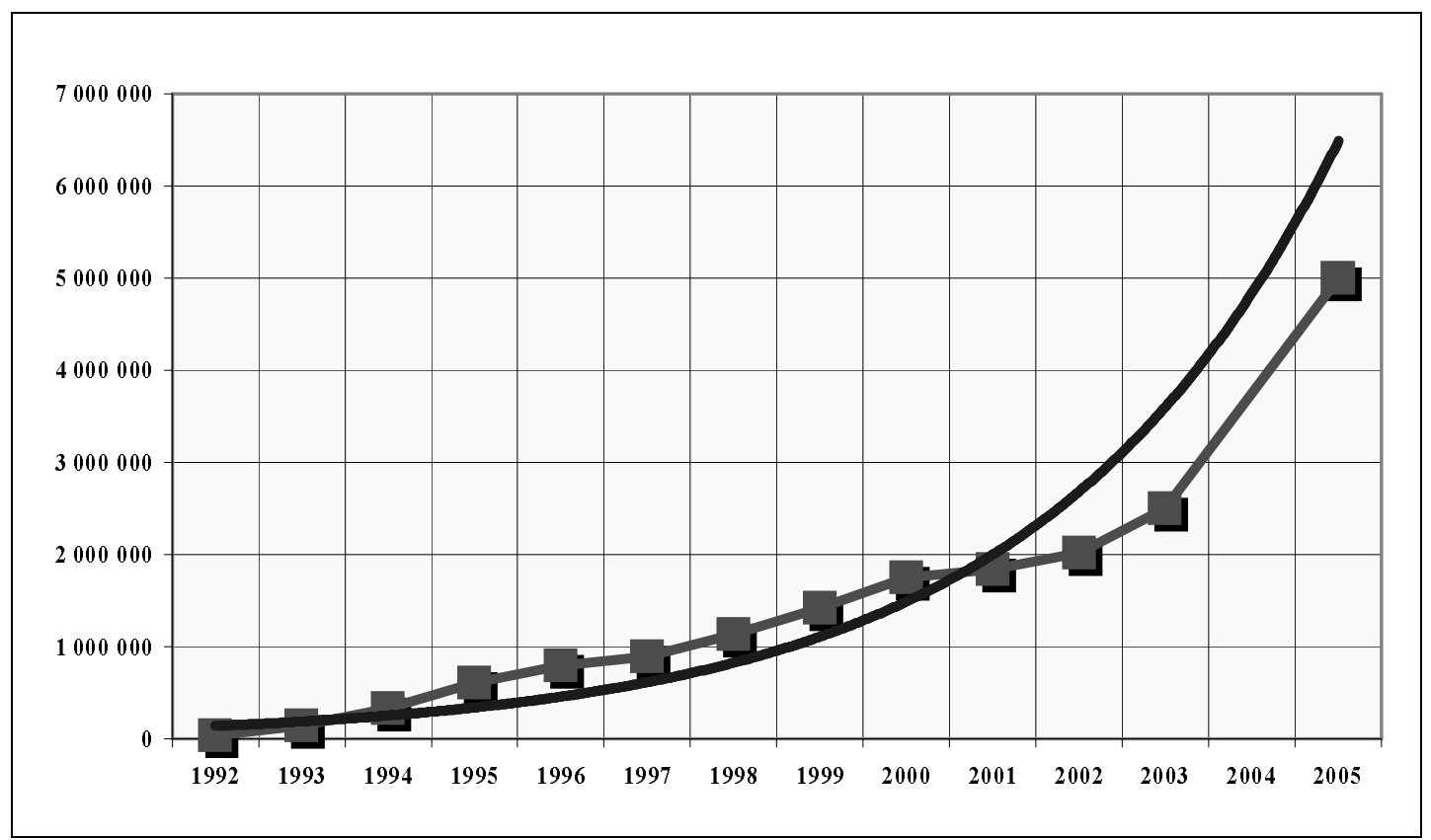

Figure 6. Sales of Navigation Systems in Japan

It is obvious that navigation systems have been very popular only Japan. In the United States and Europe, they have been acquired only by top-of-the-range consumers buying luxury brands sucg as Audi, BMW and Mercedes-Benz. This is indeed due to the relatively high price of such devices in Europe and a low demanding market in the US and Europe since the traffic is not such a constraint than on the Japanese Pacific coastal connurbation.

It is only since 2004 that prices are decreasing in Europe. But they still remain very high:

Table 2. Some examples of prices for navigation systems in France in July 2004

Unit: euro.

\begin{tabular}{|l|l|c|}
\hline Factory-fit & Citroën Picasso & 1,150 \\
\hline Factory-fit & Peugeot 407 & 1,270 \\
\hline Factory-fit & VW Golf & 1,495 \\
\hline Factory-fit & Renault Megane & 2,140 \\
\hline Factory-fit & Japan & 600 \\
\hline Main Street France & Cheapest Website & 750 \\
\hline
\end{tabular}

\footnotetext{
${ }^{14}$ Source: Nihon Keizai Shimbun, 02/05/2002.
} 


\section{SCENARIOS FOR THE FUTURE ITS TECHNOLOGIES}

This section deals a specific part of "ITS", namely in-vehicle driving assistance systems. Obviously ITS encompass much more than that, e.g. also systems for electronic toll collection, traffic management, and incident detection, and further research would be needed for extending or elaborating alternative options for the other ITS domains.

This section is based on the following four assumptions: there are still some scientific and technical bottlenecks; the economic feasibility is still far from proven; the social acceptance of such devices is still questionable; there is an absolute requirement for a strong political and legal support.

The future of vehicle driving assistance systems is very dependent on the bargaining power of the various stakeholders of the industry, i.e. the OEMs and their component suppliers, the customers and the various government agencies.

For in-vehicle driving assistance devices, four pricing strategy seem to be envisageable:

- Premium innovator's or monopoly pricing as it happened for the ABS and navigation systems in the past: this model requires a low demand elascticity and no oligopolistic competition;

- Competitive market pricing, i.e. at marginal manufacturing cost: this strategy is highly uncertain since acceptability and then demand are unknown due to the lack of product information;

- Kamikase pricing; with an extreme limit to $p=0$ as Linux, this model is very risky since it aims a creating an entirely new market;

- Welfare pricing. based on market pricing reduced by a public subsidy or any other financial incentive.

\subsection{Market acceptance}

There is indeed no published market research for in-vehicle driving assistance products so far. In the context of this project realised within for the French programme ARCOS 2003, a survey has been carried out on Internet with a representative panel of 558 persons. When asked to prioritize the key factors for road safety, $85 \%$ of them point the improvement of the drivers' behavior, $8 \%$ the improvement of infrastructures and only $5 \%$ the improvement of vehicle equipment.

Within 480 respondents, $64 \%$ declared to be ready to invest in safety. But only $17 \%$ admitted to have already invested in optional safety devices, and 60\% recognized that Euro NCAP tests have no influence on their decision when purchasing a new car. 


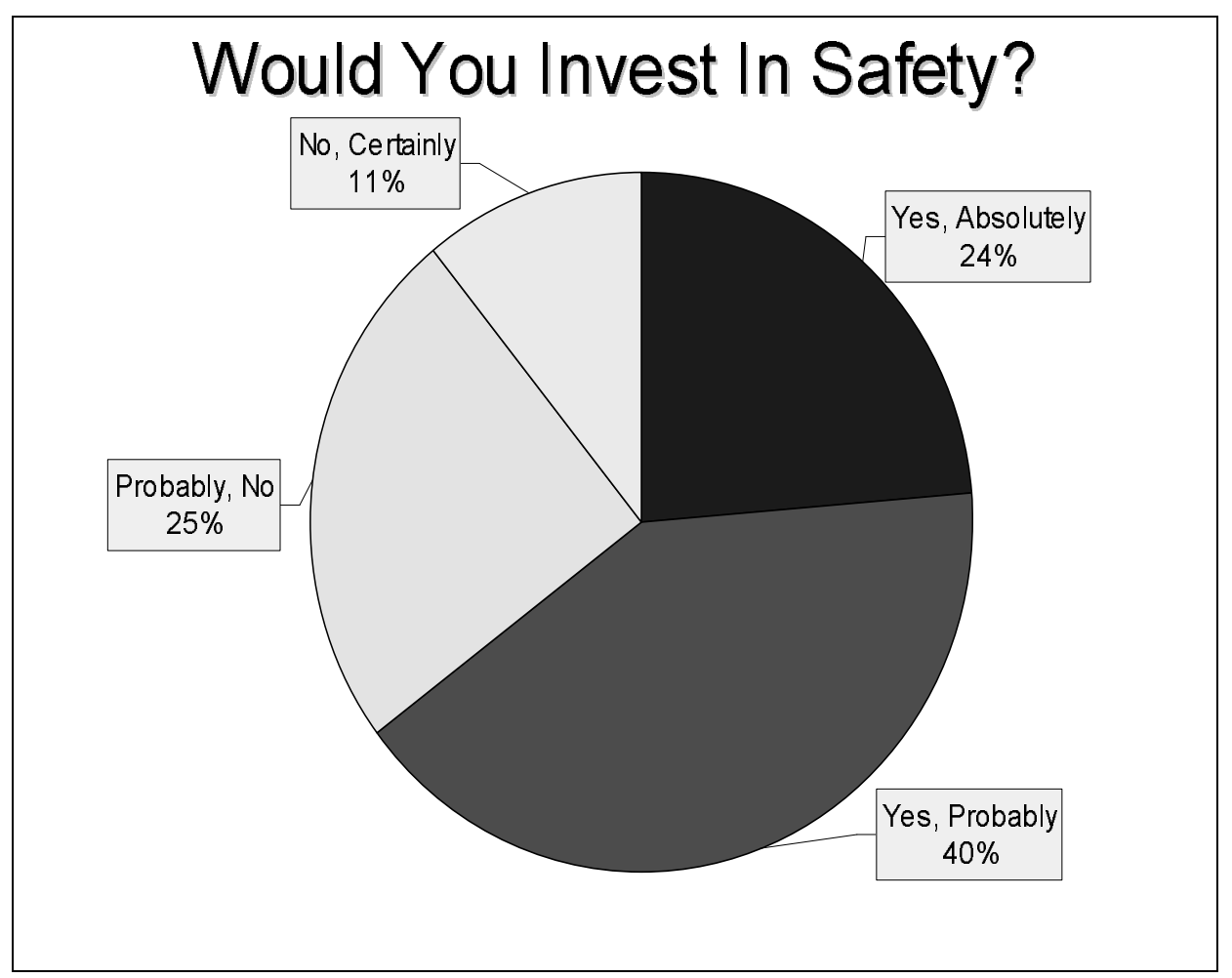

Figure 7. Investing in safety

To the question "how much are you ready to spend?", $15 \%$ of the 311 workable answers declared they would accept to pay more than $€ 1,000$.

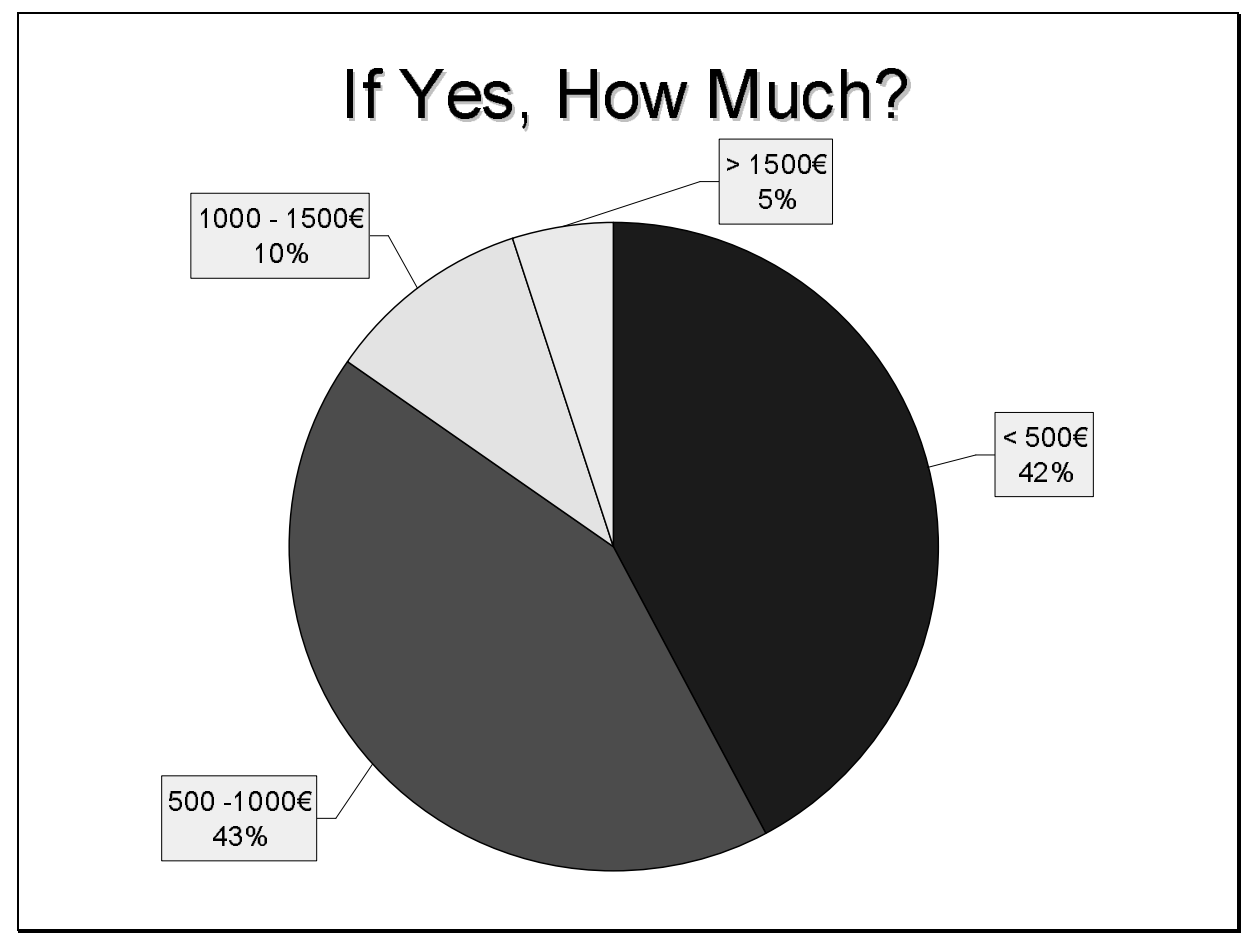

Figure 8. Which level of investment in safety?

In previous research (Chanaron \& Kostopoulou 1995a; Chanaron, 2001), it has been indicated that psychological ceiling prices do exist in the automtive system, i.e. that the average customer 
is usually fixing a limit to the price she/he is ready to pay for a particular good or service; and that several evidences from consulting organizations indicate a level of ceiling at $€ 300-400$.

\subsection{Business models}

It is possible that the only solution for in-vehicle driving assistance devices would be a mix of several generic business models:

\section{The subscription business model}

It is based on selling the service and up-date through subscription. Best examples are magazines. It provides a constant revenue stream but requires high marketing and tracking costs. The crucial remaining question: what about hardware pricing?

2. The razor-blade business model

It is based on cheap hardware with revenue from "consumable" or "associated services". Best examples are mobile telephone, TV.. It has the same unresolved question: what about hardware pricing?

\section{Network effects business model}

It is based on the principle that a product-service has value only thanks to the number of existing customers. A technological standard should be imposed providing heavy switching costs and there is a risk of anti-competition practice.

\section{Dis-intermediation business model}

It aims at direct sale and management by the OEMs and sales by main street shops and DIY supermarkets. The key objective is to reduce transaction costs;

\section{Controlled obsolescence business model}

It is based on relatively cheap hardware with R\&D and sales managed by software companies. A new generation is launched every two to four years: best example is indeed Microsoft.

6. Collective business model

All stakeholders join a non-profit association. The consortium defines and imposes a unique standard. It adopts a pricing-to-cost strategy.

\subsection{Competitive strategy}

There are two opposing options within the automotive system: a "technology-centered" vision which aims at designing a 100\% smart and safe car; and a "business-centered" approach which adopts a step-by-step fitting of safety devices.

Obviously, the OEMs and their component suppliers promote the second one, which is less risky and coherent with their interest (Chanaron, 1998). The customers would probably be supportive 
to the same strategy since the impact on prices will be very high. The first vision is the one advocated by scientists, civil servants from governmental organizations and politicians.

In a recent article, Chanaron \& Duymedjian (2004) suggested the following stakeholders' responsibility for automotive software:

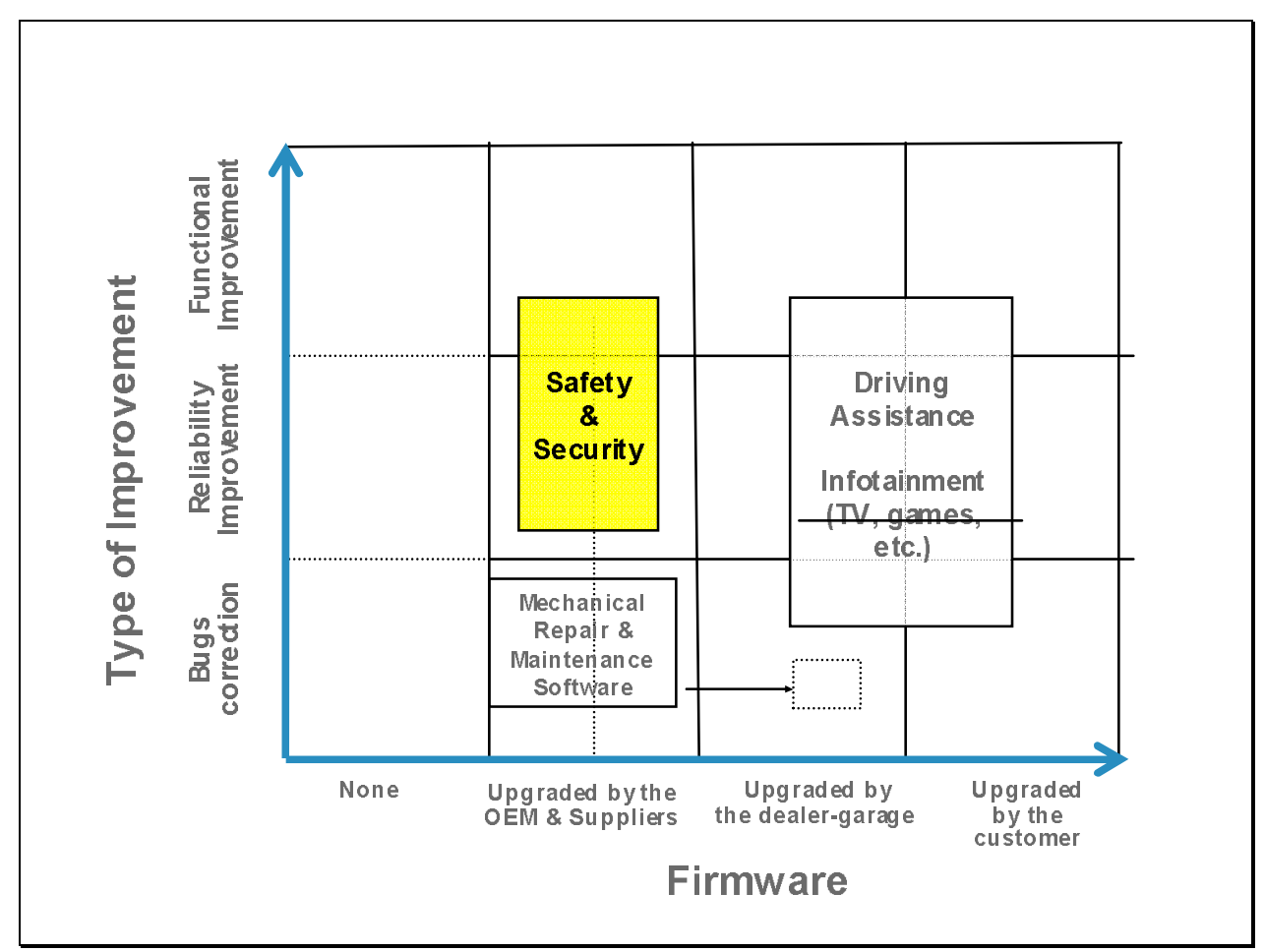

Figure 9. Automobile software development and up-grading

There is obviously a substantial impact of ITS-related devices on vehicle prices.

Table 3. Prices in Yen of ITS devices form the Toyota Crown Majesta

\begin{tabular}{|l|c|c|c|c|}
\hline System & Price Yen & Price $€$ & $\begin{array}{c}\text { Average Price } \\
\text { Vehicle }\end{array}$ & \% Price \\
\hline Lane Keeping Assisiatnce & 210000 & 158 & 6000000 & $3,5 \%$ \\
\hline Intelligent Cruise Contro1 & 178500 & 134 & 6000000 & $3,0 \%$ \\
\hline Night Vision & 315000 & 236 & 6000000 & $5,3 \%$ \\
\hline Intelligent Parking Assistance & 241000 & 181 & 6000000 & $4,0 \%$ \\
\hline Early Accident Warning System & 283500 & 213 & 6000000 & $4,7 \%$ \\
\hline Total & 1228000 & 921 & 6000000 & $20,5 \%$ \\
\hline
\end{tabular}

There is still high uncertainty to be resolved prior to volume diffusion: customer acceptance for such price differential? Technical standardization and at which level (national, continental or worldwide? What about the cost of up-dating and up-grading of software? Which level and rythm for economies of scale? Which legal responsibility and liability in case of failure?

The automotive system is also suffering from the telephone syndrome. The positive impact of vehicle driving assistance devices on safety records will be long to be visible since it will probably follow the traditional diffusion trajectory. 
- 1st step: Optional equipment

- 2nd step: Original equipment on top-of-the-range models

- 3rd step: Extension to top middle-sized

- 4th step: Extension to bottom middle-sized

- 5th strep: Generalization

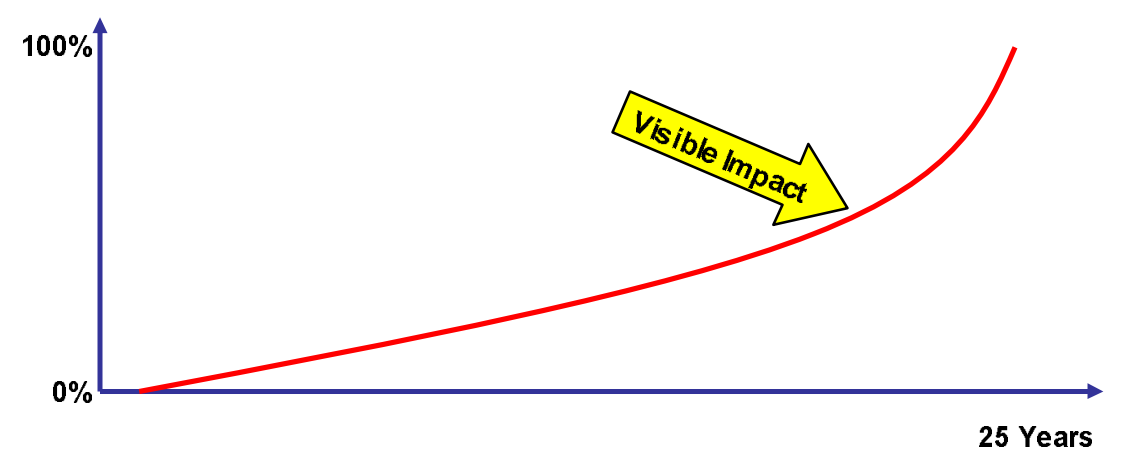

Figure 10. The telephone syndrome

Providing such crucial econmic questions would have been positively answered in the future, other uncertainties might bring new challenges into the picture such as psychological and sociological acceptance. Lewin (2005) recently pointed out the reluctance of buyers for exclusively electronically-based safety devices, i.e. drive-by-wire systems such as brake-by-wire and steering-by-wire ${ }^{15}$, requested anyway for future deployment of in-vehicle driving assistance systems.

\section{CONCLUSION}

In no way does this paper claim to be exhaustive. Neither does it refer to literature on recent microeconomic theory - work on game theory, in particular ${ }^{16}$ - or experimental economics ${ }^{17}$, which provide numerous analyses of price determination in situations of imperfect competition and competitive oligopolies.

It places particular emphasis on the concepts and notions used to support, or justify, the strategic decisions made by companies, and mirrors the ideas put forward by Smith and Nagle (1994), which infer that pricing decisions are, more often than not, of a "political" nature, which implicitly assumes that no mechanical model for the calculation of the ideal price actually exists.

\footnotetext{
${ }^{15}$ The OEM having to maintain in parallel a direct mechanical control over the function.

${ }^{16}$ See, for example, Choumette and Colard (1997) and ENSMP (2001). For a simple presentation of the applications to price theory, see the special reports by Les Echos magazine entitled "L'art de la stratégie" (The Art of Strategy), issues 3 and 4, in particular the articles by Garicano and Garicano and Gertner.

${ }^{17}$ See, for example, Capra, Goeree, Gomez, Holt, (2000) and Roth (1993). One of the major developments of contemporary experimental economics is the emergence of a new field, dubbed "design economics", which deals with the design of markets and the creation of markets through simulation (Roth, 2001).
} 
The pricing of a new product or service is clearly a strategic decision, but it is also a highly complex issue.

The analysis of two real cases of automotive innovation - ABS and navigation systemsproves the existence of a strong correlation between price and sales volume. What it does not do is provide a formula or even a vague method for determining "acceptable" price levels or "trigger points". In addition, state intervention in the automotive sector can often play a decisive role - subsidies, tax breaks - thus causing an artificial drop in the launch price and therefore accelerating an innovation's success.

The framework developed on pricing and business models for in-vehicle driving assistance systems helps understanding innovation strategies. There are two options: "breakthrough" or disruptive innovation which is by essence very risky abd completely out of automobile industry history; or "incremental innovation" with each major model renewal.

Such options exclude obviously the possibility of a radically new "entrant", i.e. an innovation introduced by another industry. It is worth pinpointing that to date there is a consensus amongst experts that such a third way has very little chance to occur. In any case, innovation would probably come from risk taking stakeholders, with long termism strategies, sustainable resources and commitment to research and development.

\section{REFERENCES}

[1]. Aliawadi, K.L., Lehmann, D.R., Neslin, S.A., (2000), Market Response to a Major Policy Change in the Marketing Mix: Learning from Procter \& Gamble's Value Pricing Strategy, Journal of Marketing, Vol. 65, nº 1 , pp. 44-61.

[2]. Briard, C., (2002), La politique tarifaire à la recherche d'une nouvelle dynamique, Les Echos, Stratégie, 25 avri1, p. 63.

[3]. Capra, A.M., Goeree, J.K., Gomez, R., Holt, C.A., (2000), Learning and Noisy Equilibrium Behavior in an Experimental Study of Imerfect Price Competition, Working Paper, University of Virginia.

[4]. Chanaron, J.J., (1991), Innovation technologique et développement économique, Cours d'Economie Appliquée, DGES, Université Pierre Mendès France, Grenoble.

[5]. Chanaron, J.J., Kostopoulou, M., (1995a), Systèmes d'incitation, changement technique et modes de consommation, le cas de l'automobile, Colloque sur les recherches françaises en économie et sciences sociales sur l'effet de serre : bilan et perspectives, Muséum d'Histoire Naturelle, Paris, 12-13 avril, Ministère de l'Environnement-ADEME.

[6]. Chanaron, J.J., M. Kostopoulou (1995b), Systèmes d'incitation, changement technique et modes de consommation, le cas de l'automobile, Ministère de l'Environnement-ADEME, avril.

[7]. Chanaron, J.J., (1998), Automobiles: a static technology, a "wait-and-see » industry?, in Chanaron, J.J., Guest Editor, Technological Change and Inertia: Case Studies, A Special Issue of The International Journal of Technology Management, Vol. 16, nº 7 , pp.595630 .

[8]. Chanaron, J.J., (2001), Innovating in Intelligent Automobile Transportation: Towards anindustry-wide consortium?, The International Journal of Automobile Technology \& Management, Vol. 1, $\mathrm{n}^{\circ}$ 2-3, pp. 252-268. 
[9]. Chanaron, J.J., Orselli, J., (2001), Vers la conduite automatisée ? Les systèmes de transports intelligents, Paris, Paradigme, Avril.

[10]. Chanaron, J.J., Duymedjian, R., (2004), Business Models for Software: from Generic to Automobile-specific Models, Les Cahiers du Management Technologique, Vol. $13 / 3$.

[11]. Choumette, F., Colard, F., (1997), La théorie des jeux, downloaded from http://perso.wanadoo.fr/frederic.colard/theojeux/theojeux.htm.

[12]. Cressmann, G.E., (1991), Successful Business Strategy Needs a Consistent Pricing Policy, downloaded from http://www.strategicpricinggroup.com.

[13]. ENSMP, (2001), Eléments de la théorie des jeux, Slides of lectures, ENSMP.

[14]. European Commission, (2001), Getting Proces Right, Results from the transport research programme, Luxembourg, July.

[15]. Garicano, L., (2001), La théorie des prix : 1'art d'en tirer parti, L'art de la stratégie, Les Echos, $n^{\circ} 3$..

[16]. Garicano, L., Gertner, R., (2001), La dynamique de la guerre des prix, L'art de la stratégie, Les Echos, ${ }^{\circ} 4$.

[17]. Holden, R.K., Nagle, T.T. (1998), Kamikaze Pricing, Marketing Management, Summer, pp. 31-40.

[18]. Johnson, G., Scholes, K., (2002), Exploring Corporate Strategy, Financial Times, Prenice Hall, $6^{\text {th }}$ edition.

[19]. Kelly, L.S., (1996), Pricing of High-Technology Products, Les Cahiers du Management Technologique, $n^{\circ} 16$, janvier-avril.

[20]. Kahaner D.K.,(1996), Car Navigation System Activities in Japan, atip96.049, June $3^{\text {rd }}$.

[21]. Khalaf, L., Kichian, M., (2000), Testing the Pricing-to-Market Hypothesis: Case of the Transportation Equipment Industry, Bank of Canada Working Paper 2000-8, May.

[22]. Klemperer, P., (1987), Markets with Consumer Switching Coists, The Quarterly Journal of Economics, Vol. 102, n², pp. 375-394.

[23]. Klemperer, P., (1995), Competition when Consumers have Switching Costs: An Overview with Applications to Industrial Organization, Macroeconomics, and International Trade, Review of Economic Studies, n62, pp. 515-539.

[24]. Lewin, T., (2005), The Intelligent Car: How to interact with the latest top model, Special Report Motor Industry, Financial Times, March 1.

[25]. Noble P.M., P.M., Gruca, T.S., (1999), Industrial Pricing: Theory and Managerial Practice, Marketing Science, Vol. 18, No. 3.

[26]. Office Links (2001), Developing a pricing strategy for your products and services, downloaded from http://www.officelinks.com/marketing/mktg20 pricing.htm.

[27]. Pei-Yu, C., Hitt, L.C., (2001), Measuring Switching Costs and their Determinants in the Internet-Enabled Businesses: A Study of the On-line Brokerage Industry, Working Paper, University of Pennsylvania, Wharton School.

[28]. Pourquery, D., (2001), Introduction au dossier "Stratégie de prix et techniques de pricing", L'Expansion Management Review, n 103, Décembre, p. 43. 
[29]. Roth, A.E., (1993), On the Early History of Experimental Economics, Journal of the History of Economic Thought, 15, Fall, pp. 184-209.

[30]. Roth, A.E., (2001), The Economist as Engineer: Game Theory, Experimentation and Computation as tools for Design Economics, forthcoming in Econometrica, downloaded from $\underline{h t t p: / / w w w . e c o n o m i c s . h a r v a r d . e d u / ~ a r o t h / p a p e r s / e n g i n e e r . p d f . ~}$

[31]. Sahay, A. (1998), Finding the right international mix, Financial Times, Mastering Marketing Series, Nov. $16^{\text {th }}$.

[32]. Sahay, A., (2000), Trouver le bon mix à l'international, Les Echos.

[33]. Schindehutte, M., Morris, M.H., La politique des prix comme comportement entrepreneurial, L'Expansion Management Review, nº 103, Décembre, p. 44-53.

[34]. Smith, G.E., Nagle, T.T., (1994), Financial Analysis for Profit Driven Pricing, MIT Sloan Management Review, Vol. 35, n³, pp. 71-80.

[35]. Tanokura, Y. (2001), Destination Dashboard, Nikkei Electronics, downloaded from http://www.lookjapan.com/LBsc/01DecFacts.htm.

[36]. Trends In Japan, (1998), Information on Wheels: Car-Navigation Systems Are Getting Smarter, June $9^{\text {th }}$, downloaded from http://jin.jcic.or.jp/trends98/honbun/ntj980605.html.

\section{Complementary Sources}

\section{Management textbooks}

[37]. Daly, J.L., (2001), Pricing for Profitability: Activity-Based Pricing for Competitive Advantage, John Wiley \& Sons.

[38]. Dolan, R.J., Simon, H., (1997) Power Pricing : How Managing Price Transforms the Bottom Line, Free Press.

[39]. Engelson, M., (1995), Pricing Strategy : An Interdisciplinary Approach, Joint Management Strategy.

[40]. Nagle, T.T., Holden, R.K., (2002), The Strategy and Tactics of Pricing, Third Edition, Prentice Hall, ISBN 0-13-026248-X.

[41]. Razgaitis, R., (1999), Early-Stage Technologies : Valuation and Pricing (Intellectual Property-General, Law, Accounting \& Finance, Management, Licensing, Special Topics, John Wiley \& Sons.

[42]. Reichheld, F.F., (1996), The Loyalty Effect: The Hidden Force Behind Growth, Profits, and Lasting Value, Boston, MA: Harvard Business School Press.

[43]. Vives, X., (2000), Oligopoly Pricing, MTT Press.

\section{Internet Sites}

[44]. Strategic Pricing Group, http://www.strategicpricinggroup.com. 